\title{
EVALUATION OF PLASTIC COMPOSITES MADE WITH Laccosperma secundiflorum AND Eremospatha macrocarpa CANES
}

\author{
Olufemi O. Adefisan ${ }^{1}$, Liqing Wei', Armando G. McDonald ${ }^{2,-}$
}

\begin{abstract}
The feasibility of using rattan canes (Laccosperma secundiflorum and Eremospatha macrocarpa) as reinforced fillers for high density polyethylene based plastic composite production was investigated. Extruded composites were tested for water sorption, tensile and thermal properties. The results obtained indicated that the rattan composites were dimensionally (water absorption: 2,2-21,4\% thickness swell: $0,9-5,3 \%)$ and thermally stable $\left(\mathrm{T}: 116,8-118,2^{\circ} \mathrm{C}\right)$ and possessed adequate tensile properties $(7,3-21,7$ $\mathrm{MPa}$ ). Composites made from L. secundiflorum had higher strength and thermal properties but lower sorption values compared to those of E. macrocarpa. Differences in the densities of the composites and the anatomical structures of the rattans seemed to influence properties of the composites.
\end{abstract}

Keywords: Diffusion coefficient, rattan, strength properties, swelling, thermal properties, water absorption.

\section{INTRODUCTION}

Wood plastic composites (WPC) are susceptible to durability problems of enhanced water absorption and thickness swelling (Fabiyi and McDonald 2010, Wei et al. 2013). Therefore, their use in exposed environments is limited. This setback can be curtailed by the incorporation of thermoplastic matrix which would provide moisture barriers to the wood elements and thus integrate the production of composites adaptable for exterior uses (Fabiyi and McDonald 2010). In this regard, WPCs are now used for seat backs, exterior under-flooring in the automobile industries, cases for electronic devices such as laptops and in decking, doors and windows frames in the construction industry (Gardner et al. 2015) and are reported to have adequate flexural and tensile properties (flexural strength: 26-54 MPa, flexural modulus: 2,3-3,2 GPa, tensile strength: 15-24 MPa) (Fabiyi et al. 2011, Wei et al. 2013, Pickering et al. 2016). While wood flour produced from mill residues serves as a low cost filler and reinforcement in WPCs production, however, in certain parts of the globe wood flour supply may be limited due to economic pressures resulting from the over exploitation of the available timber resources. Therefore, an alternative furnish to wood flour that are accessible without problems of collection and haulage are required in developing countries like Nigeria. A candidate furnish material for the production of plastic composite is rattan, a versatile climbing palm available in abundance in forests of western Nigeria (Adefisan 2010).

Rattans are a short rotation crop and can be harvested in less than seven years after planting. Rattans can be processed with simple and inexpensive technology (Olorunnisola 2005). Almost all parts of the rattan plants are useful. For example, the skin is good for weaving and as a binding material in furniture making. The stem (cane) is used for household materials, furniture and sport equipment (Figure 1). The cores of the canes are also used for weaving while the leaves are used as curtains and roofing materials (Vongkaluang 2002). Different rattan species such as Laccosperma, Eremospatha and Calamus exhibit different strength and anatomical properties (Dahunsi 2000, Lucas and Dahunsi 2004, Adefisan 2010)

\footnotetext{
${ }^{1}$ Department of Agricultural and Environmental Engineering, Faculty of Technology, University of Ibadan, Oyo State, Nigeria. E-mail: femiadefisan@hotmail.com,

${ }^{2}$ Renewable Materials Program, Department of Forest, Rangeland and Fire Sciences, University of Idaho, Moscow, USA.

E-mail: armandm@uidaho.edu

•Corresponding author: armandm@uidaho.edu
}

Received: 06.03.2017 Accepted: 19.08.2017 
which may influence the properties of the composite products. Lucas and Dahunsi, (2004) noted that $L$. secundiflorum, C. deerratus and E. macrocarpa had respective flexural strengths of 91,41 and $11 \mathrm{MPa}$ and flexural moduli of 1,$1 ; 3,4$ and $0,52 \mathrm{GPa}$. The respective fiber lengths of the species were $0,28-1,6$ $\mathrm{mm} 0,34-1,5 \mathrm{~mm}$ and $0,2-2,5 \mathrm{~mm}$. Also, while strengthening tissues (sclerenchyma) were prevalent in the $L$. secundiflorum species, preponderance of storage tissue was observed in the $C$. deerratus and $E$. macrocarpa species (Dahunsi 2000, Adefisan 2010).

However, rattan being a lignocellulosic material contains inherent sugars which is susceptible to fungal and insect attacks. Over $20 \%$ of the harvested canes for furniture manufacture are discarded due to discoloration resulting from fungal staining and inflexibility. These are oftentimes disposed by onsite incineration (Olorunnisola and Adefisan 2002, Adefisan and Olorunnisola 2011). In addition, only $20 \%$ of the 600 known rattan species produce the most sought-after fine quality canes of commercial value (Adefisan and Olorunnisola 2011). To enhance complete material utilization, rattan residues or downgraded canes have been used in plastic based composites. Recently, the tensile properties of Calamus manan rattan polypropylene composites, with the addition of talc nucleating agent, were examined by Balakrishna et al. 2012, Balakrishna et al. 2013, Balakrishna et al. 2014. They found the tensile strength and moduli were between 17-27 MPa and 1,2-1,3 GPa, respectively. Also, flexural properties (MOR and MOE) of E. macrocarpa and L. secundiflorum plastic composites were found to range between 25-28 MPa and 2,7-3,3 GPa, respectively (Adefisan et al. 2016). These composites did not include coupling agents. Furthermore, the thermal degradative behavior of these composites was also determined.

In all WPC and natural fiber-plastic composites adhesion between the fiber and plastic is of significant importance (Gardner et al. 2015, Gallagher and McDonald 2013). The addition of coupling agents such as maleated polyethylene (MAPE) and maleated polypropylene (MAPP) added to WPC formulations improve the interfacial adhesion between fibers and the matrix and results in improved composites performance (Kim et al. 2006, Demir et al. 2006, Gardner et al. 2015). The aim of this study was to evaluate the use of Nigerian grown rattan fiber in plastic composites produced by extrusion. The rattan fibers were characterized and the composite tensile, thermal and physical properties determined.

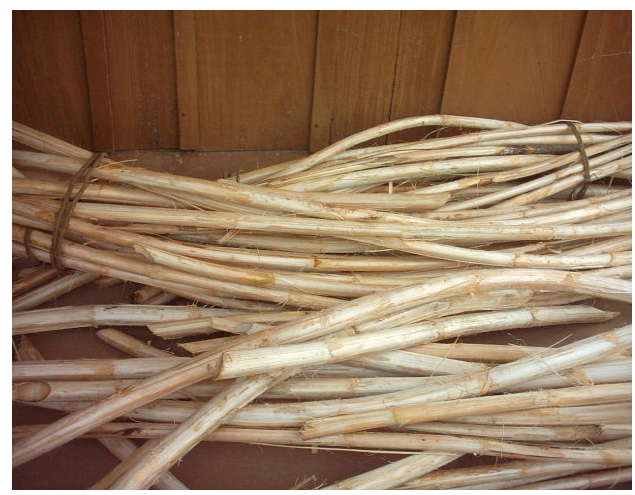

Figure 1. Photo of rattan canes.

\section{MATERIALS AND METHODS}

\section{Production of fiber reinforced plastic composites}

Rattan canes of E. macrocarpa (EM) and L. secundiflorum (LS) harvested from Gambari Forest Reserve (longitude $50^{\circ} 44^{\prime} \mathrm{E}$ and latitude $7^{\circ} 14^{\prime} \mathrm{N}$ ) in Ibadan were hammer milled to provide a 60 mesh fraction and dried to $0,5 \%$ moisture content. HDPE $(60 \% \mathrm{w} / \mathrm{w})$ (Equistar petrothene, LB 0100-00, MFI $=0,3 \mathrm{~g} / 10 \mathrm{~min}$, and density $\left.=0,950 \mathrm{~g} / \mathrm{cm}^{3}\right)$, rattan cane fiber $(38 \% \mathrm{w} / \mathrm{w})(\mathrm{EM}, \mathrm{LS}$ and 1:1 mixture of EM and LS) and MAPE (Polybond 3029, Crompton) coupling agent ( $2 \% \mathrm{w} / \mathrm{w})$ were blended in $500 \mathrm{~g}$ batches and then compounded on a $18 \mathrm{~mm}$ co-rotating twin-screw extruder (Leistritz, LD ratio 40, 200 
rpm) and extruded into a ribbon $\left(1,5 \times 50 \mathrm{~mm}^{2}\right)$ (Wei et al. 2013). The barrel and die temperature was between 140 and $160^{\circ} \mathrm{C}$.

\section{Properties Characterization of Rattan reinforced Plastic Composites}

\section{Optical Microscopy}

Optical microscopy was performed on the fiber samples on an Olympus BX51 microscope at 40x magnification equipped with a DP70 digital camera. Fiber measurements (length and width) were performed on 100 fibers for each sample.

\section{Rattan Characterization}

Air dried samples of the rattan canes (4-5g) were Soxhlet extracted with dichloromethane $\left(\mathrm{CH}_{2} \mathrm{Cl}_{2}\right.$, $150 \mathrm{ml}$ ) for a period of $20 \mathrm{~h}$ according to ASTM D1108-96. The $\mathrm{CH}_{2} \mathrm{Cl}_{2}$ extract was then evaporated to a constant weight and yield (extractive content) determined gravimetrically. The lignin content was determined on extractive free samples using the Klason lignin method according to a modified ASTM D1106-96 procedure. More specifically, the dried extractive free sample $(200 \mathrm{mg})$ was incubated in $72 \% \mathrm{H}_{2} \mathrm{SO}_{4}(2 \mathrm{~mL})$ for $1 \mathrm{~h}$ at $30^{\circ} \mathrm{C}$, then diluted into $4 \% \mathrm{H}_{2} \mathrm{SO}_{4}$, and subjected to secondary hydrolysis in an autoclave $\left(117 \mathrm{KPa}\right.$ and $\left.121^{\circ} \mathrm{C}\right)$ for $30 \mathrm{~min}$. The hydrolyzate was filtered to obtain Klason lignin content gravimetrically. Rattan ash content was determined gravimetrically by furnacing the samples at $600^{\circ} \mathrm{C}$ for $16 \mathrm{~h}$. All analyses were done in duplicate.

\section{Sorption and Mechanical Properties of composites}

Water absorption (WA) and thickness swell (TS) tests were conducted following a modified ASTM D570-98 procedure. Five replicate specimens $\left(1,5 \times 20 \times 50 \mathrm{~mm}^{3}\right)$ from each HDPE/rattan species combination were immersed in water at $23^{\circ} \mathrm{C}$ for 61 days and dimensions periodically measured. Weight gain and thickness swell were measured on a total composite basis for determination of WA and TS respectively. The diffusion coefficients of the rattan composites were calculated using the equation adopted by Fabiyi et al. (2011):

$$
\mathrm{D}_{\text {coefficient }}=\pi\left(\mathrm{h} / 4 \mathrm{M}_{\infty}\right)^{2}(\delta \mathrm{M} / \delta \sqrt{ } \mathrm{t})^{2}
$$

Where $\mathrm{M}_{\infty}$ is the maximum moisture content (MC) (\%) measured at the end of the test, $h$ is the sample thickness $(\mathrm{m})$ corresponding to $\mathrm{M}_{\infty}$, $\mathrm{t}$ is the time (s) and $\delta \mathrm{M} / \delta \sqrt{\mathrm{t}}$ is the initial slope from the graph of $\mathrm{MC}$ versus $\delta \sqrt{ } \mathrm{t}$ relation.

Tensile tests were performed on machined dog-bone samples $\left(1,5 \times 20 \mathrm{~mm}^{2}\right)$, five replicates, in accordance with ASTM Standard D638-03 with a constant strain rate of $5 \mathrm{~mm} / \mathrm{min}$ applied on an Instron 5500R-1132 universal test machine and strain measured using an extensometer (model 3542, Epsilon Technology Corp.). Data was collected and processed using Bluehill v2 software (Instron).

\section{Thermal characterization}

\section{Thermal Stability}

Thermogravimetric analysis (TGA) was conducted using a Perkin Elmer TGA 7 instrument. Specimens $(4-5 \mathrm{mg})$ were analyzed at a heating rate of $20^{\circ} \mathrm{C} / \mathrm{min}$ from 50 to $600^{\circ} \mathrm{C}$ in a nitrogen atmosphere $(30 \mathrm{~mL} / \mathrm{min})$ and analyzed using Pyris v8 software (Perkin Elmer).

\section{Thermal Analysis}

Differential scanning calorimetry (DSC) was performed on samples (4-6 mg), (in duplicate) using a TA Instruments model Q200 DSC with refrigerated cooling. The samples were (i) equilibrated at $70^{\circ} \mathrm{C}$ (3 min) then ramped to $180^{\circ} \mathrm{C}$ at $10^{\circ} \mathrm{C} / \mathrm{min}$, held isothermally for $3 \mathrm{~min}$, (ii) cooled to $70^{\circ} \mathrm{C}$ at $10^{\circ} \mathrm{C} /$ 
min and held isothermally for $3 \mathrm{~min}$ and the cycles repeated. Data were analyzed using TA Universal Analysis v4.4A software. The degree of crystallization of HDPE was calculated from the ratio of the melting enthalpy $\left(\Delta \mathrm{H}_{\mathrm{f}}^{\circ}, 105-145^{\circ} \mathrm{C}\right)$ of the sample to $\Delta \mathrm{H}_{\mathrm{f}}^{\circ}$ of $100 \%$ crystalline HDPE $\left.293 \mathrm{~J} / \mathrm{g}\right)$.

\section{RESULTS AND DISCUSSIONS}

\section{Fiber Morphology}

The fiber lengths of the EM and LS canes were $465 \pm 324 \mu \mathrm{m}$ and $416 \pm 266 \mu \mathrm{m}$ respectively while the widths were $143 \pm 76 \mu \mathrm{m}$ and $145 \pm 86 \mu \mathrm{m}$, respectively (Figure $2 \mathrm{a}$ and Figure $2 \mathrm{~b}$ ). Both fiber samples contained a mixture of tissue types (parenchyma cells and sclerenchyma cells) and determining levels of each was not performed.

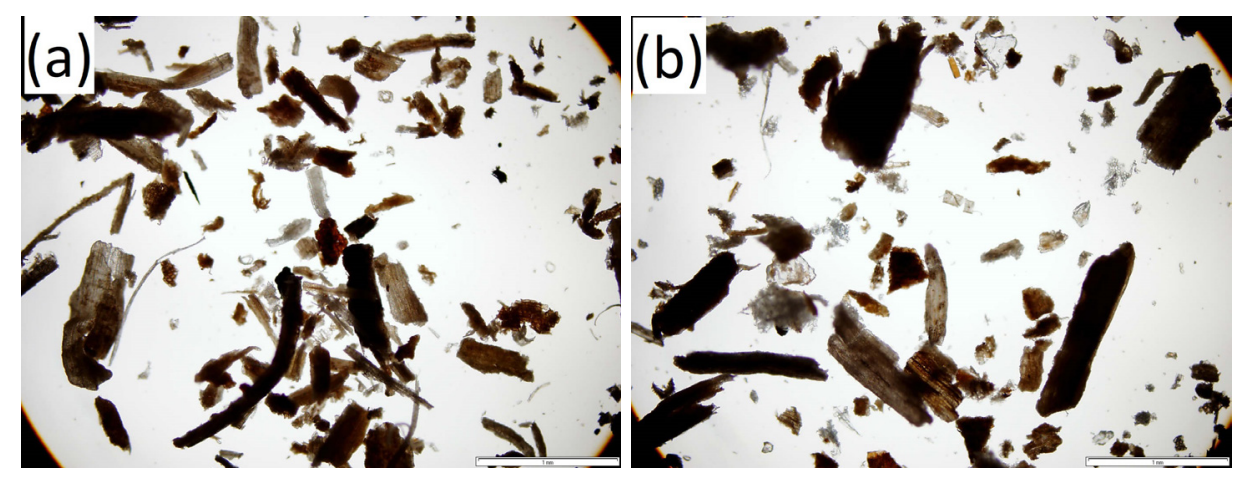

Figure 2. Optical micrographs of (a) E. macrocarpa and (b) L. secundiflorum rattan fibers (40x, scale bar $1 \mathrm{~mm})$.

\section{Chemical Properties of Rattan}

The extractives, lignin and ash contents of the rattan samples were determined. Both EM and LS rattan have an extractives content of $0,8 \%$. The lignin contents of EM and LS were 23,1 and 21,6\% respectively. While, Lamperti et al. (2014) reported lower lignin values at 17,3 (EM) and 12,9\% (LS). The ash content for EM and LS were 1,6 and 11,8\% respectively and literature values of 3\% reported for both by Lamperti et al. (2014).

\section{Rattan plastic composites}

The water soak (TS and WA) properties of the composites were measured with time (Table 1, Figure 3). Figure 3 shows data for WA in the rattan composites reaching a pseudo-equilibrium state in accordance with Fickian behavior (Rangaraj and Smith 2000).

Table 1. Sorption properties of rattan plastic composites.

\begin{tabular}{|c|c|c|c|c|c|c|}
\hline \multirow{2}{*}{ Rattan composites } & Density $\left(\mathrm{kg} / \mathrm{m}^{3}\right)$ & \multicolumn{2}{|c|}{ Water absorption (\%) } & \multicolumn{2}{|c|}{ Thickness Swell (\%) } & $\begin{array}{c}\text { Diffusion } \\
\text { coefficient } \\
\left(10^{-13} \mathrm{~m}^{2} / \mathrm{s}\right)\end{array}$ \\
\hline & & 1 Day & 61 Days & 1 Day & 61 Days & \\
\hline EM & $837(35)$ & $5,4(0,6)$ & $20,8(3,5)$ & $1,0(0,9)$ & $5,3(0,9)$ & 0,78 \\
\hline LS & $993(12)$ & $2,2(0,6)$ & $7,9(0,5)$ & $0,9(0,3)$ & $5,2(0,4)$ & 0,50 \\
\hline LS+EM mix & $794(39)$ & $3,5(0,6)$ & $21,4(1,6)$ & $1,1(0,8)$ & $4,0(0,5)$ & 1,69 \\
\hline
\end{tabular}

\footnotetext{
* Standard deviation in parentheses.
} 


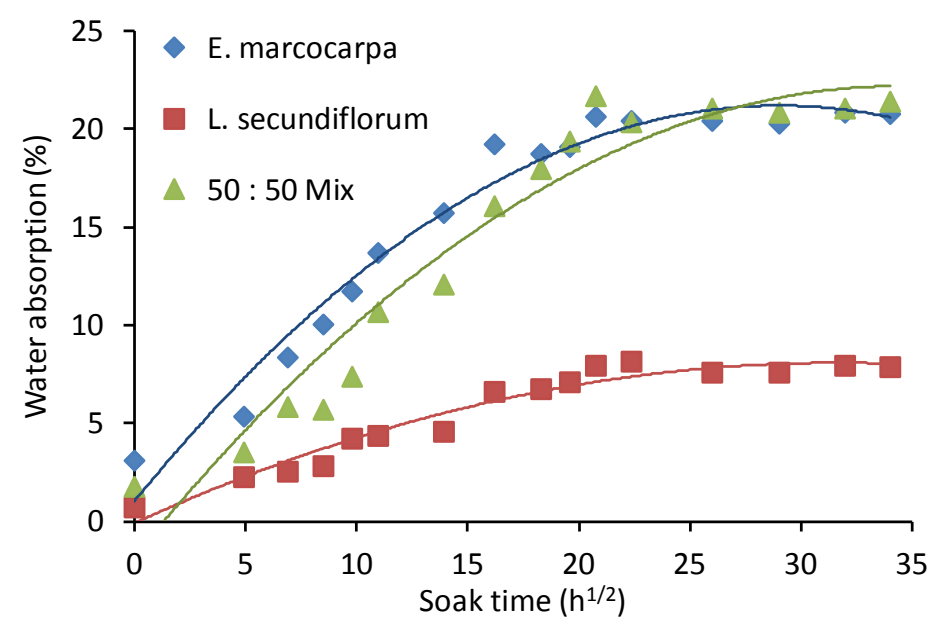

Figure 3. Water sorption of EM, LS and EM+LS rattan composites as a function of time ${ }^{1 / 2}$ in relation to Fickian law of diffusion with a second order polynomial curve fitting.

The rattan composite density appears to be a major influence in water soak properties. LS based composites had the highest density $\left(993 \mathrm{~kg} / \mathrm{m}^{3}\right)$ and the least water sorption properties. Also, the anatomical structure of the rattan canes may be another factor that affected the sorption properties. Dahunsi (2000) and Adefisan (2010) observed differences in the anatomy of rattan species. The LS rattan possesses an abundance of strengthening tissues (sclerenchyma cells) while the ES rattan has a preponderance of storage tissues (parenchyma cells). The observed differences in the sorption properties of the rattan plastic composites may be attributed to the differences in the anatomical structures (Figure 2).

Table 2. Strength Properties of Rattan Plastic Composites.

\begin{tabular}{|c|c|c|c|}
\hline Composite & Tensile Strength $(\mathrm{MPa})$ & Modulus of Elasticity $(\mathrm{GPa})$ & Energy at Break $(\mathrm{J})$ \\
\hline EM & $13,7^{\mathrm{B}}(0,9)$ & $1,15^{\mathrm{B}}(0,17)$ & $0,225^{\mathrm{B}}(0,07)$ \\
\hline LS & $21,7^{\mathrm{A}}(2,9)$ & $1,66^{\mathrm{A}}(0,29)$ & $0,423^{\mathrm{A}}(0,21)$ \\
\hline EM+LS & $7,3^{\mathrm{C}}(4,3)$ & $0,77^{\mathrm{B}}(0,43)$ & $0,123^{\mathrm{B}}(0,06)$ \\
\hline
\end{tabular}

* Means with the same letters and in the same column are not statistically different

Standard deviation in parentheses

The tensile strength and modulus of elasticity of the EM, LS and EM+LS composites and their mixtures were 13,$7 ; 21,7$ and 7,3 $\mathrm{MPa} ; 1,15 ; 1,66$ and $0,77 \mathrm{GPa}$ (Table 2). These values compared favorably with 17-27 MPa and 1,2-1,3 GPa, recorded by Balakrishna et al. 2012, Balakrishna et al. 2013, Balakrishna et al. 2014. The tensile strength, tensile modulus and energy at break of the plastic composites varied significantly among the species tested. The LS composites had significantly higher tensile properties than the EM. Again, differences in the densities and the anatomical features of the rattans tested may be responsible for the observed variation. Pickering et al. (2016) observed that fiber length is species dependent and that long fibers may get tangled during compounding resulting in poor fiber dispersion and interfacial bonding. The longer fiber length of the E. marcocarpa species (465 $\mu \mathrm{m})$ in comparison with $(416 \mu \mathrm{m})$ of the L. secondiflorum species may have resulted in lower tensile strength recorded in this study.

\section{Thermal analysis}

The thermal stability of the composites was evaluated by TGA (Figure 4). All thermograms show a small weight loss before $100^{\circ} \mathrm{C}$, associated with water loss. The weight loss due to thermal degradation of the rattan composites occurred in four distinctive stages $(\alpha, \beta, \gamma$, and $\omega)$ between 50 and $490^{\circ} \mathrm{C}$ (Fabiyi and McDonald 2010, Shebani et al. 2009, Poletto 2016) (Table 3, Figure 4a). The degradation stage $<400^{\circ} \mathrm{C}$ of composites can be mainly attributed to the decomposition of rattan chemical components such as hemicelluloses $\left(150-350^{\circ} \mathrm{C}\right)$, lignin $\left(250-490^{\circ} \mathrm{C}\right)$, extractives and cellulose $\left(275-350^{\circ} \mathrm{C}\right)(\mathrm{Kim}$ et 
al. 2006, Wei et al. 2013). From the differential thermogravimetric (DTG) curves it can be seen more clearly that the major decomposition of HDPE occurred in the stages between 327 and $468^{\circ} \mathrm{C}$ (Figure $4 b$ ). From TGA analysis the LS composites had the highest decomposition temperatures, followed by the EM and LS+EM composites (Figure $4 \mathrm{~b}$ and Table 3). It seems the thermal stability was positively correlated to the density of composites. This could be due to the higher degree of crystallinity of HDPE in the LS based composites, since it has been found that the crystalline structure can hinder the thermal degradation of polymers (Hong et al. 2011). Furthermore, the higher thermal stability for the LS composites, than the EM composites, could also be attributed to the rattan higher ash content $(11,8$ versus $1,6 \%$ ) (Poletto 2016).

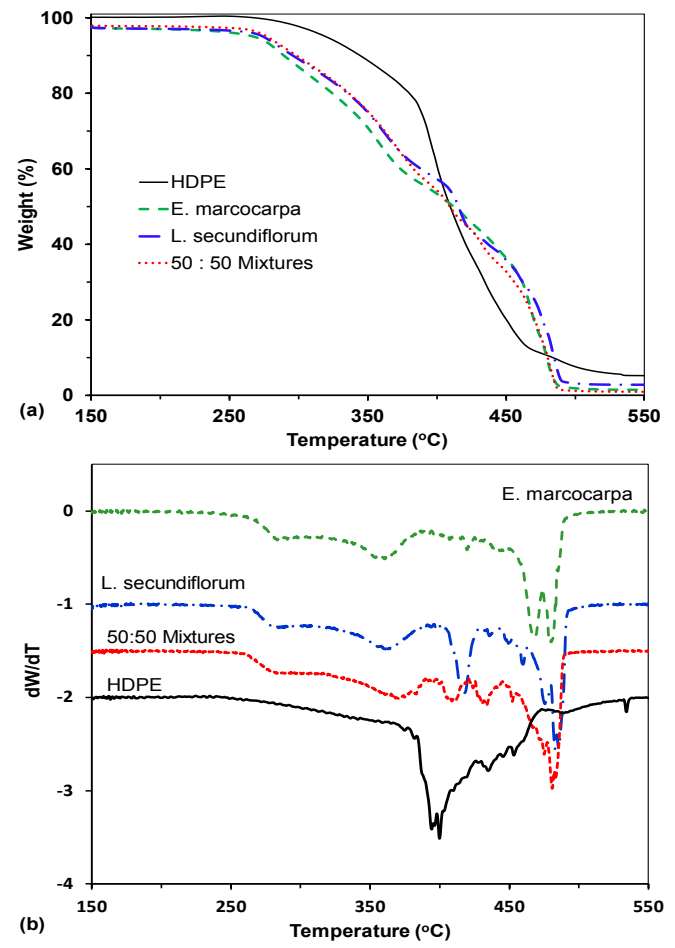

Figure 4. TGA (a) and DTG (b) thermograms of HDPE and EM, LS, and EM-LS plastic composites.

Table 3. Thermal Decomposition Temperatures of Rattan Plastic Composite.

\begin{tabular}{|l|c|c|c|c|c|c|c|c|}
\hline \multirow{3}{*}{ Composites } & \multicolumn{9}{|c|}{ First stage } & \multicolumn{9}{c|}{ Second stage } & \multicolumn{2}{c|}{ Third stage } & \multicolumn{2}{c|}{ Fourth stage } \\
\cline { 2 - 9 } & \multicolumn{9}{|c|}{ Temperature ${ }^{\circ} \mathrm{C}$} \\
\cline { 2 - 9 } & $\alpha 1$ & $\alpha 2$ & $\beta 1$ & $\beta 2$ & $\gamma 1$ & $\gamma 2$ & $\omega 1$ & $\omega 2$ \\
\hline EM & 271 & 324 & 324 & 381 & 404 & 443 & 443 & 487 \\
\hline LS & 272 & 334 & 334 & 377 & 408 & 446 & 446 & 490 \\
\hline EM+LS & 270 & 327 & 327 & 389 & 404 & 438 & 438 & 486 \\
\hline HDPE & 271 & 327 & 327 & 468 & 468 & 535 & - & - \\
\hline
\end{tabular}

* numerical subscripts ( 1 and 2 ) on the Greek letters refer to the temperatures at the first onset and final decomposition.

The degree of HDPE crystallinity in the rattan composites was determined by DSC and data given in Table 4. These values were comparable to those of Wei et al. (2013) and Gallagher and McDonald (2013) for WPC. The extent of crystallinity and the crystallization temperature $\left(\mathrm{T}_{\mathrm{C}}\right.$ ) of the LS composites were again higher than in composites made from EM and EM+LS mixture. Wei et al. (2013) observed that reduction in crystallinity of wood plastic composites oftentimes results in lower tensile strength and modulus. The higher crystallinity of the LS composites over those of the EM and EM+LS mixture 
may account for the higher strength properties observed in this study.

Table 4. HDPE crystallization temperatures and crystallinity of rattan plastic composites. Standard deviation is given in parentheses.

\begin{tabular}{|c|c|c|}
\hline Composites & $\mathrm{T}_{\mathrm{C}}\left({ }^{\circ} \mathrm{C}\right)$ & Crystallinity $(\%)$ \\
\hline EM & $116,9(1,2)$ & $52,5(0,6)$ \\
LS & $118,2(0,5)$ & $62,4(2,4)$ \\
EM+LS & $116,8(1,3)$ & $57,4(3,7)$ \\
\hline
\end{tabular}

\section{CONCLUSIONS}

Rattan canes polyethylene composites were successfully produced. The fabricated rattan plastic composites possessed adequate tensile strengths, thermal and dimensional stability comparable with those in literature. Differences in the densities of the composites and anatomical structures of the tested rattans composites seemed to affect the properties of the plastic composites produced. Rattan fiber can be used as a substitute for wood flour for producing plastic composite materials in locations where wood resources are limited.

\section{REFERENCES}

Adefisan, 0.0. 2010. Anatomical and pre-treatment effects on the hydration of cement-bonded composites from rattan canes (Calamus deerratus and Laccosperma secundiflorum). Ph.D Thesis Department of Agricultural and Environmental Engineering, University of Ibadan.178pp.

Adefisan, O.O.; Olorunnisola, A.O. 2011. Factors influencing prospective uses of rattan canes as furnish for cement composites production. In: Popoola, L., Ogunsanwo, O.Y., and Idumah, F. (ed.) $34^{\text {th }}$ Annual Conference of Forestry Association of Nigeria $5^{\text {th }}-10^{\text {th }}$ December, 2011. Conference Hall, Centre for Black Culture and International understanding, Osun State Secretariat, Okepupa, Abere Osun State. Pp: 137-142.

Adefisan, O.O.; Fabiyi, J.S.; Englund, K. 2016. Strength and thermal stability of fiber reinforced plastic composites made from rattan canes. African Journal of Sustainable Development 6(2): 283-294.

ASTM international (ASTM D 570-98). 2008. Standard test method for water absorption of plastics. In Annual book of ASTM standards. Vol. 08(01)35-38. West Conshohocken, PA

ASTM international (ASTM D 638-03). 2008. Standard test method for tensile properties of plastics. In Annual book of ASTM standards. Vol. 08(01)50-64. West Conshohocken, PA.

ASTM International (ASTM D 1106-96). 2006. Standard test method for acid-insoluble lignin in wood. In Annual book of ASTM standards. Vol. 04(01)183-184. West Conshohocken, PA.

ASTM International (ASTM D 1108-96). 2006. Standard test method for dichloromethane solubles in wood. In Annual book of ASTM standards. Vol. 04(01)187-188. West Conshohocken, PA.

Balakrishna, N.S.; Ismail, H.; Othman, N. 2012. The effect of rattan filler loading on properties of rattan powder-filled polypropylene composites. Bioresources 7(4):5677-5690.

Balakrishna, N.S.; Ismail, H.; Othman, N. 2013. The effect of rattan filler loading on mechanical properties and morphological study of rattan powder filled polypropylene composites. Adv Materials Res 626:1010-1014.

Balakrishna, N.S.; Ismail, H.; Othman, N. 2014. Polypropylene/rattan powder/kaolin hybrid composites: processing, mechanical and thermal properties. Polymer-Plastics Technology and Engineering 53: 451-458. 
Dahunsi, B.I.O. 2000. The properties and potentials application of rattan canes as reinforcement materials in concrete. Ph.D. Thesis. Department of Agricultural Engineering. University of Ibadan. 284 p.

Demir, H.; Atikler, U.; Balkose, D.; Tihminlioglu, F. 2006. The effect of fiber surface treatments on the tensile and water sorption properties of polypropylene-luffa fiber composites. Composites Part A 37(3):447-456.

Fabiyi, J.S.; McDonald, A.G. 2010. Effect of wood species on property and weathering performance of wood plastic composites. Composites Part A 41(10): 1434-1440.

Fabiyi, J.S.; McDonald, A.G.; Morrell, J.J.; Freitag, C. 2011. Effects of wood species on durability and chemical changes of fungal decayed wood plastic composites. Composites Part A 42(5): 501-510.

Gallagher, L.W.; McDonald, A.G. 2013. The effect of micron sized wood fibers in wood plastic composites. Maderas-Cienc Tecnol 15(3):357-374.

Gardner, D.J.; Han, Y.; Wang, L. 2015. Wood-plastic composite technology. Curr Forestry Rep $1: 139-150$

Hong, S.G.; Hong, T.K.; Huang, S.C. 2011. Enhancement of the crystallization and thermal stability of polyhydroxybutyrate by polymeric additives. $J$ Therm Anal Calorim 103(3): 967-975.

Kim, H.S.; Kim, S.; Kim, H.J.; Yang, H.S. 2006. Thermal properties of bio-flour-filled polyolefin composites with different compatibilizing agent type and content. Thermochim Acta 451(1-2):181-189.

Lamperti, A.M.; French, A.R.; Dierenfeld, E.S.; Fogiel, M.K.; Whitney, K.D.; Stauffer, D.J.; Holbrook, K.M.; Hardesty, B.D.; Clark, C.J.; Poulsen, J.R.; Wang, B.C.; Smith, T.B.; Parker, V.T. 2014. Diet selection is related to breeding status in two frugivorous hornbill species of Central Africa. Journal of Tropical Ecology 30: 273-290.

Lucas, E.B.; Dahunsi, B.I.O. 2004. Characteristics of three western nigerian rattan species in relation to their utilisation as construction material. Journal of Bamboo and Rattan 3(1):45-56.

Olorunnisola, A.O.; Adefisan, O.O. 2002. Trial production and testing of cement-bonded particleboard from rattan furniture waste. Wood and Fiber Science 34(1): 116-124.

Olorunnisola, A.O. 2005. Dimensional stability of cement-bonded composites boards from rattan cane particles. Journal of Bamboo and Rattan 4(2):173-182.

Pickering, K.L.; Efendy, A.M.G.; Le, T.M. 2016. A review of recent developments in natural fibre composites and their mechanical performance. Composites: Part A 83:98-112.

Poletto, M. 2016. Effect of extractive content on the thermal stability of two wood species from Brazil. Maderas-Cienc Tecnol 18(3): 435-442.

Rangaraj, S.V.; Smith, L.V. 2000. Effects of moisture on the durability of a wood thermoplastic composite. Journal of Thermoplastic Composites Material 13(2):140-161.

Shebani, A.N.; VanReenen, A.J.; Meincken, M. 2009. The effect of wood species on the mechanical and thermal properties of wood-LLDPE composites. J Composite Materials 43(11):13051318.

Vongkaluang, I. 2002. Thai rattan in the early 2000. In. J. Dransfield, F.O. Tesoro and N. Manokaran eds. Non-Wood Forest Products 14. Rattan Current Research Issues and Prospects for Conservation and Sustainable Development. P. 183 - 189. F.A.O., Rome.

Wei, L.; McDonald, A.G.; Freitag, C; Morrell, J.J. 2013. Effects of wood fiber esterification on properties, weatherability and biodurability of wood plastic composites. Polymer Degradation and Stability 98: 1348-1361. 